\title{
Online peer feedback
}

\section{Brugen af Peergrade i universitetsundervisning}

Karen Louise Møller, Center for Undervisningsudvikling og Digitale medier, Aarhus Universitet Mette Løvschal, Arkæologi og kulturarvsstudier, Aarhus Universitet og Moesgaard Museum

\section{Abstract}

Peergrade er et digitalt redskab, der kan anvendes til at understøtte peer feedback aktiviteter. I denne artikel beskrives anvendelsen af redskabet $i$ universitetsundervisning, nærmere betegnet $i$ faget Forhistorisk Arkæologi II på Aarhus Universitet. Aktiviteterne var ikke obligatoriske, men de forbedrede portfolio-opgaver indgik i de studerendes individuelle eksamensportfolio, der blev afleveret forud for mundtlig eksamen i faget. Vi beskriver her de studerendes oplevelser på baggrund af deres svar på spørgeskema og deltagelse i fokusgruppeinterview. Vi slutter af med anbefalinger for brug af peer feedback aktiviteter med Peergrade i universitetsundervisning.

\section{Engelsk abstract}

Peergrade is a digital tool that can be used to support peer feedback activities; This article describes the use of the tool in university teaching, more specifically in the subject Prehistoric Archeology II at Aarhus University. The activities were not compulsory, but the improved portfolio assignments were included in the students' individual exam portfolio, which was handed in prior to the oral examination in the subject. We describe the students experiences based on their responses to the questionnaire and participation in focus group interview. We describe recommendations for using peer feedback activity with Peergrade in university teaching. 


\section{Indledning}

Feedback spiller en vigtig rolle for studerendes læringsudbytte (Hattie \& Timperley 2007), da de med feedback får mulighed for at reducere kløften mellem nuværende og ønskede forståelse. Der har derudover været stort fokus på studerendes muligheder for at modtage feedback i undervisningen i de senere år. Feedback kan leveres af flere kilder, hvoraf én er de medstuderende. Med afsæt i en socialkonstruktivistisk læringsforståelse ønskede vi at udvikle peerfeedback aktiviteter, hvor de studerende fik mulighed for at give og modtage peerfeedback på seks forskellige skriftlige opgaver. I planlægningen af aktiviteterne var vi opmærksomme på, at det har betydning for læringsudbyttet, at anvende den modtagne feedback (Nicol 2010), og derfor går peerfeedback aktiviteterne forud for aflevering af en eksamens-portfolio der rummer de seks forbedrede opgaver. De studerende har således mulighed for at anvende peer feedbacken til at forbedre deres opgaver inden aflevering af eksamensopgaven.

Vi ønskede i dette studie at undersøge, hvordan bachelorstuderende på Arkæologi og Kulturarvsstudier på Aarhus Universitet oplevede at deltage i peer feedback aktiviteter mellem undervisningsgangene med henblik på at forbedre anvendelsen af digitale peer feedback-redskaber i undervisningsforløbene.

Undervisningsforløbet fandt sted i efteråret 2018 og 2019. I undervisningen var der ikke afsat tid til, at underviseren kan give individuel feedback til de studerendes portfolio-opgaver. Dette har tidligere haft den konsekvens, at størstedelen af de studerende ventede med at skrive deres seks portfolio-opgaver til de allersidste uger i semesteret. Dermed gik de studerende glip af muligheden for at bruge portfolioopgaverne til at arbejde med det faglige indhold løbende og forbedre deres læringsudbytte af undervisningen undervejs. Introduktionen af peer-feedback aktiviteter i løbet af semesteret gav således de studerende mulighed for at modtage peer-feedback på deres portfolio-opgaver fra medstuderende og løbende at arbejde med opgaverne, herunder forbedre dem inden endelig aflevering (Løvschal 2018).

\section{Det digitale redskab}

I forløbet anvendtes redskabet Peergrade, der automatisk fordeler de studerendes opgaver mellem dem efter en angivet deadline for opgavens aflevering. Underviser kan følge med i afleverings- og feedbackprocessen uden at bruge lang tid på at organisere aktiviteterne. Processen følger et fast skema, hvor de studerende først afleverer deres opgave via et link; derefter giver de feedback til et fastsat antal medstuderende, og endelig får de herefter adgang til den feedback, de selv har modtaget fra deres medstuderende. I Peergrade er der yderligere mulighed for, at de studerende kan reagere på den feedback, de har modtaget i form af afkrydsning (fra 'very helpful' til 'not helpful') suppleret med et tekstfelt til uddybende kommentarer. Denne funktion blev ikke anvendt.

Inden oprettelsen af de seks opgaver i Peergrade formulerede underviser 6-8 rubric-spørgsmål til hver opgave. Disse spørgsmål skulle den studerende besvare, når vedkommende gav peer feedback. Underviser brugte tid på at formulere klare og præcise spørgsmål (Reddy \& Andrade 2010), der udformedes med udgangspunkt i kursets beskrivelse og studieordning. Spørgsmålene udviklede sig fra at være møntet på at give feedback på opgavens form, sprog og formalia i de første opgaver til i større omfang at rette sig mod opgavens faglige indhold og argumentation.

\section{Undervisningsforløbet og eksamensformen}

Kurset er bygget op om 12-18 undervisningsgange, der består af en kombination af forelæsninger og praktiske øvelser (fx studier af genstande og deres kontekst, udredning af husplaner og diskussioner af tekster). Der var sat en deadline for aflevering af en individuel portfolio-opgave hver 2.-3. uge; det samlede portfolio skulle afleveres ved kursusforløbets afslutning inden afholdelse af den mundtlige 
eksamen. Portfoliet skulle afleveres som en forudsætning for at gå til mundtlig eksamen, men talte derudover ikke med i bedømmelsen.

Emnerne for portfolioopgaverne fulgte de undervisningsemner, der blev gennemgået på kurset, og udviklede sig gradvist fra beskrivelsesfokuserede opgaver til opgaver, der stillede krav om mere reflekterende og kritisk diskuterende besvarelser. Peer feedback-aktiviteterne fandt sted mellem undervisningsgangene og havde til formål at sikre kvalitet og progression i de seks skriftlige portfolioafleveringer, samt at træne de studerende i at give feedback på baggrund af instruktioner fra underviser. I forløbets første time introducerede underviser det digitale redskab Peergrade som en del af beskrivelsen af undervisningsforløbets mål og indhold og demonstrerede, hvordan de studerende skulle tilgå redskabet ved hjælp af en kode. Desuden talte underviser med de studerende om fælles forventninger til aktiviteterne, fx hvordan man gav god feedback samt feedbackens formål i forhold til kursets læringsmål. Herunder ses et eksempel på en anvendt opgaveformulering og de dertil tilknyttede rubric-spørgsmål:

\section{Portfolio opgave 5}

Beskriv hovedtrækkene i Grøntoft-landsbyens udvikling i løbet af ældre førromersk jernalder. Max 4800 tegn og minimum fem referencer.

\section{Rubric-spørgsmål}

1. Giver besvarelsen en systematisk gennemgang af hovedtrækkene i Grøntoft-landsbyens udvikling?

2. Hvordan har den studerende beskrevet både de uindhegnede landsbyer og den indhegnede landsby (A)?

3. Afspejler besvarelsen, at den studerende har overblik over den generelle udvikling af landsbyen? Giv eksempler på, hvordan.

4. Har den studerende anvendt detaljerede arkæologiske observationer, fx strategrafiske relationer og indgange i fælleshegnet, til at underbygge sin redegørelse? Hvilke/ hvordan?

5. Er sproget flydende og præcist? Hvad kan forbedres?

6. Er der anvendt relevant litteratur fra pensum og er den korrekt referenceret (i teksten og i referencelisten)?

7. Opfylder besvarelsen formalia til porteføljerne? (Max 4800 tegn og minimum fem referencer)

Vi valgte at lade både forfatter og peer feedback-giver optræde anonymt i peer feedback-aktiviteterne, eftersom der findes erfaringer med, at dette kan føre til bedre og mere kritisk feedback (Lu \& Bol 2007). Underviseren har dog undervejs adgang til afsender-identitet på både opgaver og peer feedback-bidrag. Eftersom det var de studerendes første møde med en skriftlig peer feedback-aktivitet på universitetet, blev det besluttet, at de skulle give feedback på to portfolio-opgaver fra medstuderende i hver peer feedback aktivitet. Dette for samtidigt at gøre det mindre sårbart for den studerende, hvis en enkelte medstuderendes feedback var mindre udførlig eller eventuelt fraværende. Kurset blev afsluttet med en mundtlig individuel eksamen.

\section{Metode}

I kurset deltog 17 studerende (2018) og 20 studerende (2019). Undervisningsforløbet og aktiviteterne var tilnærmelsesvist de samme i 2018 og 2019. 
Deltagelsen i feedbackaktiviteterne var et tilbud, alligevel deltog 15 studerende i 2018 og 15 studerende i 2019. I slutningen af semesteret bad vi de studerende fra $2018 \mathrm{om}$ at besvare et spørgeskema (SS2018), der blev distribueret via kurset i Blackboard (9 responderede anonymt). I 2019 indbød vi tre studerende til et fokusgruppeinterview (FG2019).

Spørgsmålene i spørgeskemaet var møntet på at undersøge de studerendes oplevelse med aktiviteterne og deres oplevede læringsudbytte ved at deltage. Vi valgte at gennemføre en spørgeskemaundersøgelse i 2018 for at få så mange svar som muligt fra de deltagende studerende. Vi stillede 13 spørgsmål, hvor vi spurgte ind til de studerendes oplevelse med redskabet og aktiviteterne. De studerendes svar blev tematisk kodet og kategoriseret (Kvale \& Brinkmann 2009). Data fra spørgeskemaundersøgelsen førte til et ønske om at supplere med et fokusgruppe interview for at kunne spørge ind til flere detaljer omkring de studerendes oplevelse med aktiviteterne. Dette blev gennemført i 2019.

Den aktuelle fokusgruppe bestod af to mænd og én kvinde. Vores anvendte spørgeguide rummede en række spørgsmål, som overlapper spørgsmål vi stillede i spørgeskemaet og andre spørgsmål, vi ønskede at få besvaret. Interviewet blev lydoptaget på interviewers mobiltelefon og blev gennemført på Moesgaard, Aarhus Universitet. De tre studerende blev introduceret til formålet med undersøgelsen, interviewer præsenterede sig og informerede om de studerendes anonymitet i undersøgelsen. De studerendes svar blev efterfølgende tematisk kodet og kategoriseret (Kvale \& Brinkmann 2009).

\section{Resultater og diskussion}

Fund beskrives nedenfor i fire overskrifter: De studerendes oplevelse (det praktiske), deres oplevede læringsudbytte, Præferencer for åben eller anonym proces og det vi ellers fandt.

\section{De studerendendes oplevelse (det praktiske)}

Ingen studerende nævner vanskeligheder ved at håndtere det digitale redskab Peergrade, herunder at aflevere opgaver, levere feedback og tilgå den modtagene feedback. En studerende (SS2O18) skriver:

"Det var utroligt nemt at benytte sig af - ingen problemer der" (SS2018)

og en anden studerende udtaler:

"Det fungerede helt fint, og der kom sådan nogle mails med, at så er der én dag tilbage,

husk at få afleveret, nu er feedbacken åben, så det fungerede rigtigt fint" (FG2019)

Heller ingen af de studerende beskriver vanskeligheder ved at følge underviserens instruktion, fx siger en studerende:

"Det var lige i begyndelsen af kurset, de gik igennem, hvad man skulle gøre. Det giver lidt sig selv, når man er derinde" (FG2019)

\section{De studerendes oplevede læringsudbytte}

Herunder beskrives deres oplevede udbytte ved at modtage og give feedback til andre.

De studerende finder det overvejende udbytterigt at modtage feedback fra andre. Flere studerende italesætter, at feedbacken har været hjælpsom, og flere sætter pris på, at de kan vende tilbage til den senere. De studerende nævner også nogle udfordringer. De italesætter bekymring ift. kvaliteten af den modtagne feedback, fx nævner en studerende: 
"Hvis man får et tip fra en medstuderende, er man ikke helt sikker på om han/hun har ret" (FG2019)

Samtidigt er de studerende opmærksomme på, at de fokuserer lidt forskelligt i deres feedback, fx siger en studerende:

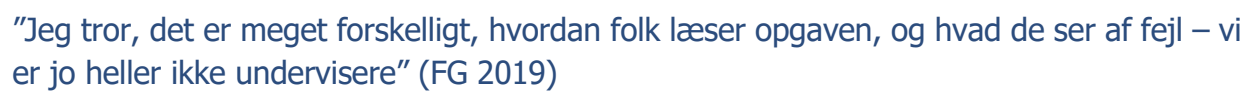

Dette understreger vigtigheden af at forberede dem på opgaven og lade dem give feedback til flere opgaver, så de modtager mere feedback, en tilgang vi også møder i andre studier (Cho \& Mac Arthur 2010).

Flere studerende italesætter en oplevet ubalance mellem omfanget af givet og modtaget feedback. Ingen beskriver at de har modtaget mere feedback end de har leveret til andre. For nogen studerende har den mindre omfattende feedback dog bekræftet dem i, at deres tekst har været tilstrækkelig, fx siger en studerende:

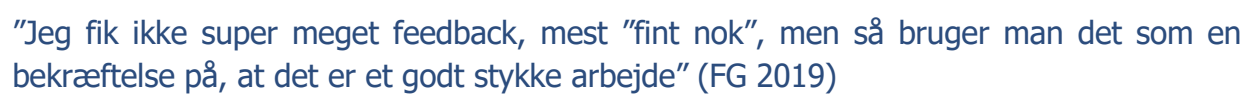

Flere af de studerende foreslår i denne forbindelse fremtidige tiltag, såsom en tydelig beskrivelse af forventningerne til arbejdsindsats. Derfor kan beskrivelse af eller dialog om forventet arbejdsindsats, samt grundig vejledning i hvordan man giver god og brugbar peer feedback være fordelagtigt fremadrettet.

Flere studerende oplever det udfordrende, at de befinder sig på forskelligt fagligt niveau. Det viser, at det er vigtigt, at flere studerende giver feedback til hver tekst, og at det er væsentligt med rubricspørgsmål, der er formuleret, så feedbackgiveren vejledes til at give en brugbar feedback. Rubricspørgsmål kan fx udformes således, at det er lægges vægt på, at man skriver mere end "ja”/"nej”, fx kan man bede den studerende om at levere forbedringsforslag, så feedbackgiver ikke alene udpeger mangler eller roser opgaven.

Alle studerende har fundet det udbytterigt at give feedback til deres medstuderende, hvilket er i tråd med andre studier (Lundström 2009). Når de studerende giver feedback til en medstuderende, oplever de at kunne hente inspiration, fx skriver en studerende:

"Man kunne se andres måder at besvare opgaven og derved bruge det selv som inspiration" (SS2018)

og en anden siger:

"Der er måder at vende sætninger på, som man kan lære" (FG 2019)

Flere nævner, at de har fået ideer til opgavernes opbygning og fået øje på vigtigt indhold, som de selv har glemt at inddrage, fx siger en studerende:

"Den opgave opfylder ikke helt kravene ..(..).. gør min egen opgave så det?" (FG2019)

Dette udsagn peger på, at indblikket i medstuderendes opgaver giver muligheder for at tænke og reflektere over deres egne opgavers indhold.

De studerende oplever, at rubric-spørgsmålene er hjælpsomme i processen. En studerende siger: 
"Generelt virkede de godt ..(..).. de fik én til at tænke på, hvad man skulle huske ..(..).. de viser, hvad vi skal fokusere på" (FG2019)

En studerende foreslår, at rubric-spørgsmålene gøres synlige på forhånd, eftersom enkelte spørgsmål var overraskende. En studerende bemærker:

"Det havde jeg slet ikke tænkt på, at jeg skulle prioritere i opgaven" (FG2019)

En anden studerende foreslår, at rubric-spørgsmålene opfordrer til at beskrive, hvad den studerende kan forbedre. I processen fik nogle studerende mulighed for at læse en god besvarelse, og de har uden tvivl haft mulighed for at lære noget værdifuldt. De studerende som gav feedback til mindre gode opgaver, har haft mulighed for at arbejde mere indgående med rubric spørgsmålene og dermed opgavens evalueringskriterier, hvilket også har været udbytterigt. I undervisning uden planlagte peer feedback-aktiviteter har de studerende sjældent adgang til medstuderendes opgavebesvarelser. Det at få mulighed for at se, hvordan en medstuderende har udarbejdet en beslægtet opgave, leverer transparens, hvilket understøtte den studerendes læring (Dalsgaard \& Paulsen 2009). Vi tænker, at hovedparten af de studerendes udbytterige oplevelser med at læse andres opgaver og give feedback i en vis grad kompenserer for enkelte studerendes oplevelse med at modtage mindre brugbar feedback.

Endelig peger flere studerende på, at peer feedback-aktiviteterne giver dem mulighed for at komme tættere på de andre studerendes faglighed, fx siger en studerende:

"Systemet hjælper med at afmystificere, hvor meget jeg er med på holdet i forhold til de andre ..(..).. for det meste vil man blive bekræftet i at det går nok - for de andres opgaver har også fejl" (FG2019)

Flere nævner derudover, at indblikket i de andres opgaver bekræfter dem i at være på rette vej med deres egen opgave, som en studerende udtrykker det:

"For de flestes vedkommende bekræfter Peergrade-aktiviteterne, at man er på rette vej man făr ro" (FG2019)

Enkelte studerende peger dog også på en udfordring, der knytter sig til egne manglende erfaringer med at give peer feedback, $\mathrm{fx}$ efterlyser en studerende at se eksempler på god feedback givet til konkrete opgaveafsnit.

\section{Åben eller anonym proces}

De studerende har forskellige præferencer mht. synlighed eller anonymitet i aktiviteterne. De studerende argumenterer således både for og imod anonymitet $i$ aktiviteterne.

Flere studerende ønsker at være anonyme, fx udtaler en studerende:

"Selvom man er på universitetet, er folk stadig nervøse omkring deres opgaver" (FG2019)

Men samtidigt er der flere studerende, der foretrækker synlighed i aktiviteterne. De fremhæver især muligheden for efterfølgende at indgå i dialog med feedbackgiver, fx skriver en studerende:

"Så man kunne spørge dem om, hvad de har tænkt og få eventuelle uklarheder afklaret"

(SS2018)

Enkelte studerende peger på, at synlighed også vil kunne afværge ærgrelser over mangelfuld feedback, fx skriver en studerende: 
".. så kan folk ikke gemme sig bag anonymitet og være dovne på det grundlag" (SS2018)

I undervisningen før hver portfolio-aflevering afsatte underviseren tid til kort at besvare spørgsmål til den kommende peer feedback-aktivitet. Temaerne var kvaliteten af peer feedbacken, samt hvorvidt de studerendes identitet burde ændres fra anonym til synlig. De studerende (2018) blev enige om, efter den fjerde portfolio-opgave, ikke længere at være anonyme i aktiviteterne. De studerende ønskede med denne ændring at forpligte hinanden på at give en bedre og mere omfattende feedback og efterfølgende have mulighed for at bede om en uddybning af feedbacken. Det er undervisers indtryk, at dette tiltag var med til at skærpe de studerendes ansvar ift. at give en grundig og konstruktiv feedback, men sandsynligvis også medårsag til, at vi oplevede et generelt fald i antal deltagere i feedback-aktiviteterne. I forhold til denne beslutning skriver en studerende:

"De sidste par Peergrade afleveringer var mest givtige, idet man kunne gå i dialog med den studerende, der havde givet peer feedback ift. forbedringer af ens opgave" (SS2018).

En anden studerende udtrykker en anden holdning:

"Hos os blev det i sidste ende ikke længere anonymt, og det syntes jeg var utrolig træls, fordi det kan gå hen og blive personligt for nogle mennesker" (SS2018)

Sidstnævnte bekymring møder vi også i andre undersøgelser (van Genneip et al. 2010; Vanderhoven et al 2015).

I 2019 optrådte de studerende anonymt i alle peer feedback-aktiviteterne.

\section{Det vi ellers fandt}

Flere studerende oplever at aktiviteterne primært har til formål at reducere underviserens arbejdsbelastning, fx siger en studerende:

"Det er jo en arbejdsbyrde, man lægger væk fra underviseren og giver den til de studerende, men jo mere underviseren engagerer sig, jo bedre vil det være" (FG2019)

De studerende ønsker undervisers feedback og undervejs gav underviser en generel feedback på de studerendes opgaver i undervisningen på baggrund af portfolio-opgave 3. Om dette fortæller en studerende:

"Underviser sagde, at det her kan I generelt forbedre - og så var der en masse punkter.

Det var en god feedback, og når alt kommer til alt, så vil vi jo egentlig alle sammen hellere have feedback fra vores underviser" (FG2019)

Samme studerende foreslår, at underviser-feedback blev givet tidligere i forløbet fx efter portfolioopgave 1, så pointer kan anvendes i de efterfølgende opgaver.

Flere studerende beskriver at aktiviteter med faste deadlines i løbet af semesteret har fungeret godt, ift. at få udarbejdet portfolio-opgaverne i god tid, fx siger en studerende:

"Det at der er en deadline - det skubber ret mange ..(..).. det har i hvert fald hjulpet mig

- ellers havde jeg siddet med det hele til sidst" (FG2019)

Antallet af studerende, der deltog i peer feedback-aktiviteterne i Peergrade, faldt i løbet af semesteret i 2018. Dette var imidlertid ikke tilfældet i 2019, hvor stort set samtlige studerende deltog i alle aktiviteter. Aktiviteterne var ikke var obligatoriske, hvilket kunne medføre at andre obligatoriske studieaktiviteter 
kunne være blevet prioriteret. Eftersom nogle studerende (2018) var bekymrede over ophævelse af anonymitet i aktiviteterne kan det også betyde, at de fravalgte aktiviteterne på baggrund af dette.

Da fokusgruppen bliver spurgt om, hvorvidt de hellere vil mødes med medstuderende ansigt til ansigt og give mundtlig feedback, beskriver de studerende både fordele og ulemper:

"Hvis man sidder over for personen, kan det være sværere at sige" (FG2019)

og

"Det er en god øvelse at sidde ansigt til ansigt, hvilket man også burde kunne håndtere på det her niveau" (FG2019)

Disse udtalelser peger på, at man med fordel kunne kombinere flere forskellige peer feedback-formater $i$ et undervisningsforløb, det være sig med og uden inddragelse af digitale redskaber.

\section{Konklusion og anbefalinger}

Ovenstående peger på, at de studerende finder det let og intuitivt at anvende det digitale redskab, og at det overvejende opleves udbytterigt både at modtage og give peer feedback. Undersøgelsen peger samtidig på nogle udfordringer, der med fordel kan arbejdes med i fremtidige undervisningsforløb, der gør brug af peer feedback-aktiviteter mellem undervisningsgangene.

Ud fra ovenstående erfaringer, vil vi særligt pege på behovet for at forberede de studerende på at give peer feedback, herunder, at man sørger for at:

1. skabe faste og trygge rammer

2. undervise i principper for god og brugbar peer feedback

3. instruere i feedback vha. teksteksempel (jf. Heger \& Hvass 2018).

Vi vil også anbefale, at

4. de studerende făr mulighed for at vælge at deltage anonymt i aktiviteterne eller deltage synligt med andre, der foretrækker det samme.

Dette minimerer risikoen for ikke-deltagelse eller frustration på grund af eventuelle krav om synlighed.

Rubric-spørgsmål er særligt et redskab, hvor underviseren med fordel kan sætte ind med formuleringer, der kræver mere af de studerende end ja/nej svar. Her foreslår vi, at de studerende

5. får mulighed for at modtage feedback fra (mindst) to medstuderende for at imødekomme udfordringer med forskelligt fagligt niveau.

6. får mulighed for at se rubric-spørgsmålene og stille spørgsmål til disse i undervisningen forud for anvendelsen i Peergrade. 


\section{Referencer}

Cho, K., \& MacArthur, C. (2010). Student revision with peer and expert reviewing. Learning and instruction, 20(4), 328-338.

Dalsgaard, C., \& Paulsen, M. F. (2009). Transparency in cooperative online education. The International Review of Research in Open and Distributed Learning, 10(3).

Lu, R., \& Bol, L. (2007). A comparison of anonymous versus identifiable e-peer review on college student writing performance and the extent of critical feedback. Journal of Interactive Online Learning, 6(2).

Hattie, J., \& Timperley, H. (2007). The power of feedback. Review of educational research, 77(1), 81-112.

Hvass, H., \& Heger, S. (2018). Brugbar peer feedback: Instruktion og træning, før de studerende selv skal give og modtage. Dansk Universitetspædagogisk Tidsskrift, 13(25), 59-70.

Kvale, S., \& Brinkmann, S. (2009). Interview: introduktion til et håndværk. Hans Reitzels Forlag.

Løvschal, M (2018). Peer feedback med Peergrade. AU Educate: http://educate.au.dk/praksiseksempler/peerfeedback/peer-feedback-med-Peergrade/

Lundstrom, K. \& Baker, W. (2009). To give is better than to receive: The benefits of peer review to the reviewer's own writing. Journal of Second Language Writing, 18(1), 30-43.

Nicol, D. 2010. "From Monologue to Dialogue: Improving Written Feedback in Mass Higher Education.” Assessment \& Evaluation in Higher Education 35(5), 501-517

Reddy, Y.M. \& Andrade, H., 2010. A review of rubric use in higher education. Assessment \& Evaluation in Higher Education, 35(4), 435-448.

Van Gennip, N.A.E., Segers, M.S.R. \& Tillema, H.H., 2009. Peer assessment for learning from a social perspective: The influence of interpersonal variables and structural features. Educational Research Review, 4(1), 41-54.

Vanderhoven, E., Raes, A., Montrieux, H., Rotsaert, T., \& Schellens, T. (2015). What if pupils can assess their peers anonymously? A quasi-experimental study. Computers \& Education, 81, 123-132.

\section{Forfattere}

\section{Karen Louise Møller}

Specialkonsulent

Center for Undervisningsudvikling og Digitale Medier

Aarhus Universtitet

\section{Mette Løvschal}

Lektor, Ledende forskningsudvikler

Arkæologi og kulturarvsstudier

Aarhus Universitet og Moesgaard
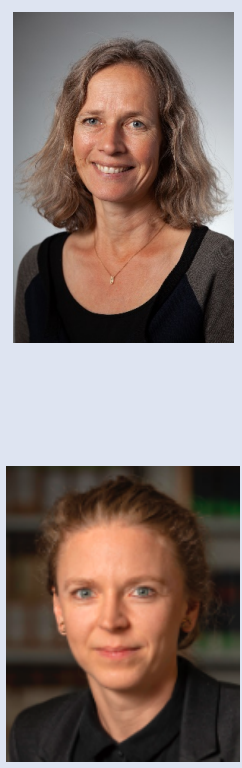